\title{
Current Trends in Competency Based Education
}

\author{
Marcela Hernández-de-Menéndez, Ruben Morales-Menendez \\ Tecnológico de Monterrey, Research and Graduate Studies, Monterrey, NL, México \\ Email: marcelahernandez@itesm.mx,rmm@itesm.mx
}

How to cite this paper: Hernández-deMenéndez, M. and Morales-Menendez, R. (2016) Current Trends in Competency Based Education. World Journal of Engineering and Technology, 4, 193-199.

http://dx.doi.org/10.4236/wjet.2016.43D023

Received: September 21, 2016

Accepted: October 13, 2016

Published: October 20, 2016

\begin{abstract}
The shortage of individuals with the abilities to perform a job position successfully demands innovative educational approaches. Competency Based Education $(C B E)$ is a methodology that focuses on endowing students with the skills demanded by the industries and evaluates them regarding what they are able to do. A bank of competencies that students must acquire in a university academic program was discussed. Occupational trends as well as associated skills demands were detected. This research could be a source of practical knowledge for those organizations seeking to understand $C B E$ foundations and for those wishing to initiate their path through this global educational trend.
\end{abstract}

\section{Keywords}

Competency Model, Competency Assessment, Learning Methods, Occupational Trends

\section{Introduction}

Currently, workforce leaders are highlighting the importance of preparing students with the abilities demanded and recognized by the industries [1]. This issue matters to both organizations and academic institutions. The former seeks to find persons with the right knowledge and competencies for developing a job position for two main reasons: improve organizations' performance and increase the satisfaction and the retention of employees [2]. The latter, looks to prepare professionals with high possibilities of being hired, as nowadays education is seen as an investment that must have a return [3]. In the US, only $11 \%$ of business leaders are strongly agree that students have the right skills to do well in a labor environment [4]. To solve this problem, a proper Competency Based Education ( $C B E$ ) model for new professionals could contribute to the cause.

It is essential that students acquire not only the specialized knowledge, but also the 
needed skills to apply it and succeed in a highly demanding and ever changing world [5]. This would be the main contribution of universities, the education of individuals with the right competencies to contribute to the present and future labor environment [6].

$C B E$ is considered by academics as an option to face these challenges [1]; it is defined as an educational system or program that measures knowledge, skills, and experience in place of or in addition to the use of credit hours [7]. The purpose is to make a beginner, in this case a student, becomes an expert in a specific field [8].

The main characteristics of $C B E$ are: an emphasis on results, a focus on development of abilities, the demonstration of competency mastery rather than time based teaching and the student as a learning unit [9]. This scheme of education focuses on evaluate students regarding what they are able to do for the society [10].

$C B E$ approach is not new; disciplines such as medicine, psychology and engineering have already a history in the field [11]. Organizations such as Alverno College, Excelsior College and Thomas Edison State College developed CBE programs in the 1970s [12]. Today, it has evolved and many universities and colleges have joined this initiative [7] [13].

This educational method, which has proven to be successful as there are more than 52 programs just in the $U S$ already using different variants [7], is considered a disruptive innovation that will continue revolutionizing Higher Education [4]. Current courses under $C B E$ offer flexibility and allow students to learn at their own pace. The individuals can assess the acquisition of a competency when they are feeling ready. New cost models have been developed [1] [7]. $C B E$ is not a trend, it has arisen from the needs of the society with the main objective of give additional value to both students and organizations [5]. It is seen as the missing link between learning outcomes and industry needs [4].

The outline of this paper is as follows: in Section 2 introduces the concept of competency. Section 3 presents a model of the basic competencies for students. Section 4 shows the $C B E$ and occupational trends. Finally, Section 5concludes the paper.

\section{Competency: An Overview}

The first step for implementing a $C B E$ initiative is to understand what a competency is. This term has a variety of definitions [2] in both educational and business context. There is lack of consensus among researchers regarding the different aspects constituting this word [12]. It is considered multidimensional, dynamic and with a developing identity, strongly influenced by the context in which it is used [14].

The UNGeneral Secretary from 1997 to 2006, Kofi Annan, defines competency as a combination of skills, attributes and behaviors that are directly related to successful performance on the job [15]. In an educational framework, a competency will specify what students can do after completing a program. The focus is on the performance and the demonstration of their abilities [11].

An own definition of competency is: A student's competency contains three ele- 
ments: knowledge, skills and attitudes/values. These components are integrated to perform a specific activity, with measurable outcomes, that clearly indicate what the student is able to do. A competency comprises a set of resources and talents an individual has to perform a particular task.

Competencies can be categorized as disciplinary or transversal. The former, as the name suggests, comprises those competencies that are particular of a discipline. The latter, which are also known as generics, are those competencies common to the different fields of study, e.g. critical thinking, effective communication, ethics, etc. [8], and facilitates the acquisition of the other ones. In some cases, a single course can contain a mix of the above competencies.

The way graduates are taught by Higher Education Institutions (HEI) has a big influence on developing significant competencies. When the aim is to develop the aforementioned abilities, the graduates learn by doing, using and interacting [6].

$C B E$ requires specific and nontraditional teaching methods [11]. Repetition and memorization of information do not allow students to understand the challenges and problems of this century. It is advisable to teach with learning experiences that stimulate them in developing the skills demanded by the industrial market [15].

The $C B E$ teaching methods should allow students to be self-directed learners, practice what is taught and receive training activities that matches with their learning style [11]. These activities require continuous practice, as the acquirement of competencies is an ongoing process; this will ensure that the new skills are strengthened and will move to the long term memory. Competency development in students is an incremental process [8].

Competency development is a function of the personal attitudes of the students plus the resources provided by the $H E I$, such as an effective teachers mentoring [6]. Using techniques and resources to promote competencies such as: minutes writes, presentations, case studies, think-pair-share, socratic questioning, debates, notes exchange, online assignments, lectures for initial competencies training, videos, laboratories, field works, individual or group projects, expert talks, in-class group discussions, role playing, online forums, games, participation in conferences as speaker, organize seminars, field trips and creative, cultural and volunteer activities. Besides, social media is a nontraditional source to learn new capabilities. A student could follow industry leaders to identify what they are reading or obtain time management tips. He could also search for infographics to get an idea on how to improve data presentation and make it more appealing [16].

One of the main characteristics of $C B E$ is the continuous evaluation required to verify that the competencies are being developed [11]. A person is competent on a task, by seeing her performs it [8]. $C B E$ assessment is perhaps more challenging than the traditional model; it requires gathering and analyzing diverse information, testing the student repeatedly and offering a personalized attention, which demands significant time [17].

Evaluation of competencies allows to determine the level of acquisition, encourages 
learners to work to achieve the goals, develops self-correction and continuous learning abilities, and modifies or improves the strategies based on the results [18].

$C B E$ assessment methods include: published papers, tests, projects, scoring rubrics [11], metacognitive reflection, portfolios [19], learning journals, self-appraisal, peer evaluation [8] and Behavioral Observation Scales (BOS) [18]. Software to track competencies are gaining momentum [20]. There are available tests to measure learning outcomes in a more accurate manner, such as, Comprehensive Assessment of Team Member Effectiveness, Leadership Q-sort Test and Leadership Ability Test, Test of Oral Communication Skills, California Critical Thinking Skills Test, Graduate Record Examination test, Test of English as a Foreign Language, and General Innovation Skills Aptitude Test.

Organizations with needs of specialized resource devote important efforts in their selection processes to attract the best candidates, those that will make important contributions to the business, organizations use formal assessment methods [21] such as Cognitive Ability Tests, Job Knowledge Tests, and Personality Tests.

\section{Basic Competencies}

The important transversal competencies were grouped in four categories based on similarities related to the expected outcomes in the performance of the students:

1) Personal performance: contains competencies will aid students to have a major impact in any context in which he works, such as, cross-cultural communication, effective communication, self-taught, world knowledge, personal management, crisis management, leadership, team-working, and networking.

2) Ethics and legality competencies will help students to proceed with integrity and within the law, such as, humanism and civic engagement, legal, sustainability, professionalism and ethical practice.

3) Supporting competencies will improve the job performance, such as, information technology, technology, argument construction, entrepreneurship, and virtual competency.

4) Intellectual competencies will ensure the work will be done correctly and with excellence, such as, critical thinking, creativity, innovation, constructing knowledge, research, decision making, problem solving, analysis capacity, and intellectual risk.

The development and adoption of $C B E$ has been evolutionary and revolutionary. It was originated by pioneering countries such as United States, Australia and United Kingdom. Nowadays, Finland, Canada, New Zealand, Sweden, Singapore and China are some of the nations that have implemented it with major achievements. There is no consensus about the number of universities that have applied $C B E$ to their degree programs. The main reason could be that, to date, there is no agreement about what is exactly this approach; besides, the quantity of providers is increasing rapidly [7]. Main discussions in $C B E$ focuses on programs in which students learn content and, at the same time, develop the competencies. The credits are earn once they demonstrate the dominance of both issues. Alverno College follows the traditional system in which stu- 
dents learn the new material and do not move to the next one until they have understood the content. They must demonstrate the acquisition of competencies only before graduation. In Western Governors University, students earn the class credits as long as they master the competencies; learners take the assessments when they feeling ready [7]. Universities are finding difficulties in adopting a full $C B E$ approach. They have different levels of implementation based on the availability of resources and the positioning/transitioning strategies [22].

\section{Trends}

The main up to date $C B E$ practices are: 1) The number of transversal competencies vary from 6 to 10,2$)$ The generic competencies most often developed are: effective communication, critical thinking, lifelong learning, cultural knowledge, problem solving, global perspective, ethics, decision making, diversity, team working and technology literacy, 3) The majority of organizations offer online learning besides on campus traditional format; the blended option is also available, 4) Teaching methods are focused on experiential learning, 5) Competencies are taught in two forms: in specific courses, and embedded in the curriculum, 6) Assessment methods used to analyze if the student has achieved the learning objectives include standard tests, assignment grades, portfolio, rubrics based on evidences, observation of the learner behavior and student selfassessment, and 7) In some cases, achievement of competencies are reported with a pass or not pass grade.

New demanded professions have been developed in the last ten years. It is estimated that $75 \%$ of children entering in primary school will have jobs that today do not even exist. It is probable that more than one third of the current desired skills by employers will be replaced by abilities not yet considered as important [23].

To detect in advance the needed competencies of the future labor market, it is necessary to be aware of what is going on globally and what is expected to occur. Six of these expected changes are_1) Technological advances will lead to a big amount of data that must be systematized to find patterns and take advantage of this knowledge, 2) There is an increment of collaboration between organizations for innovation purposes [24], 3) $36 \%$ of jobs across all industries will demand complex problem solving skills, 4) It is expected a shift in the way of working, becoming more interconnected and network oriented [24], 5) Labor environments will become multicultural, due to globalization, and multigenerational, four generations working together [24], and 6) Organizations must be able to adapt fast to new market demands and customer needs that result from changing environments.

\section{Conclusion}

$\mathrm{CBE}$ is gaining space rapidly in the global educational market. It seems it has had an organic growth as it aids to solve one important challenge: the shortage of individuals with the competencies demanded by current and future industries. This learning approach measures the knowledge, skills and experience the students acquire during a 
training period. It is focused on results. It ranges from formats in which competencies are taught and evaluated apart from the curriculum, in specific courses, to those in which, to gain the degree, the student must demonstrate solely the know-how acquired. The competencies that universities must develop are diverse and depend on the needs of the different economic sectors. Some of the generic competencies to promote are: effective communication in different languages, team working, ethical practice, humanism and civic engagement, virtual competency, information technology, critical thinking and problem solving. Learning activities are more experientials and require that the students have a deep involvement. Evaluation is more personalized and, in some cases, somewhat subjective, depending on the appreciation of the mentor. Many universities use standard tests and a mix of assessment methods with the aim of obtain more accurate results. The future looks promising to $C B E$ since it is based in the needs of a fast changing society.

\section{References}

[1] Dawson, D., Dean, J., Johnson, E. and Koronkiewicz, T. (2014) Competency-Based Education: Closing the Completion Gap. At Issue, 4, 1-8.

[2] Coffey, C. (2010) A Study of Competencies Perceived to Be Important by Professionals in Entry-Level Positions within College Students Affairs. University of Central Florida.

[3] Gaudet, C., Annulis, H. and Kmiec Jr., J. (2008) Building an Evaluation Framework for a Competency-Based Graduate Program at the University of Southern Mississippi. Performance Improvement, 47, 26-36. http://dx.doi.org/10.1002/pfi.176

[4] Weise, M.R. (2014) Got Skills? Why Online Competency-Based Education Is the Disruptive Innovation for Higher Education. EDUCAUSE Review, 49, 26-35.

[5] Hitchcock, T. (2013) Changing the Rules: Competency Based Learning in Higher Education. Retrieved June 14, 2016, from researchnetwork.pearson.com.

[6] Dávila, C.D., Mora, J.G., Pérez, P.J. and Vila, L.E. (2016) Enhancing the Development of Competencies: The Role of UBC. European Journal of Education, 51, 10-24.

http://dx.doi.org/10.1111/ejed.12162

[7] Kelchen, R. (2015) The Landscape of Competency-Based Education. Enrollments, Demographics, and Affordability.

[8] Valenzuela González, J.R., et al. (2015) Competencias Transversales para una Sociedad Basada en Conocimiento. CENGAGE Learning.

[9] Gruppen, L.D., Burkhardt, J.C., Fitzgerald, J.T., Funnell, M., Haftel, H.M., Lypson, M.L., Mullan, P.B., et al. (2016) Competency-Based Education: Programme Design and Challenges to Implementation. Medical Education, 50, 532-539. http://dx.doi.org/10.1111/medu.12977

[10] Krause, J., Portolese, L. and Schedler, C. (2015) Competency-Based Education: A Framework for Measuring Quality Courses. Online Journal of Distance Learning Administration, 18.

[11] Dilmore, T., Moore, D. and Bjork, Z. (2011) Implementing Competency-Based Education. A Process Workbook 2009-2001.

[12] Ford, K. (2014) Competency-Based Education. JACC: Cardiovascular Interventions.

[13] Jones, E. and Voorhees, R. (2002) Defining and Assessing Learning: Exploring Competen- 
cy-Based Initiatives. National Center for Education Statistics. Washington DC.

[14] Frank, J.R., Snell, L.S., Cate, O.T., Holmboe, E.S., Carraccio, C., Swing, S.R., Harris, P., et al. (2010) Competency-Based Medical Education: Theory to Practice. Medical Teacher, 32, 638-645. http://dx.doi.org/10.3109/0142159X.2010.501190

[15] Irigoin, M.E., Tarnapol, P.T., Faulkner, D.M. and Coe, G. (2002) Mapping Competencies for Communication for Development and Social Change. Turning Knowledge, Skills, and Attitudes into Action, 82.

[16] Samuel, A. (2016) Using Social Media to Build Professional Skills. Retrieved August 17, 2016, from hbr.org/2016/08/using-social-media-to-build-professional-skills.

[17] Schuwirth, L. and Ash, J. (2013) Assessing Tomorrow's Learners: in Competency-Based Education Only a Radically Different Holistic Method of Assessment Will work. Six Things We Could Forget. Medical Teacher, 35, 555-559. http://dx.doi.org/10.3109/0142159X.2013.787140

[18] Bedwell, W.L., Fiore, S.M. and Salas, E. (2014) Developing the Future Workforce: An Approach for Integrating Interpersonal Skills into the MBA Classroom. Academy of Management Learning and Education, 13, 171-186. http://dx.doi.org/10.5465/amle.2011.0138

[19] Robinson, G., Moore, C., Mctigue, K., Rubio, D. and Kapoor, W. (2015) Assessing Competencies in a Master of Science in Clinical Research Program: The Comprehensive Competency Review. Clinical and Translational Science, 8, 770-775. http://dx.doi.org/10.1111/cts.12322

[20] Scott, D.D. (2008) Competency in Nursing: A Concept Analysis. Journal of Continuing Education in Nursing, 39, 58-64. http://dx.doi.org/10.3928/00220124-20080201-12

[21] Pulakos, E.D. (2005) Selection Assessment Methods. A Guide to Implementing Formal Assessments to Build a High-Quality Workforce.

[22] Tracy, R. (2016) Is There a Continuum for Competency-Based Education?

[23] World Economic Forum (2016) The Future of Jobs. Employment, Skills and Workforce Strategy for the Fourth Industrial Revolution.

[24] Rhisiart, M. (2014) The Future of Work and Skills.

\section{Submit or recommend next manuscript to SCIRP and we will provide best service for you:}

Accepting pre-submission inquiries through Email, Facebook, LinkedIn, Twitter, etc. A wide selection of journals (inclusive of 9 subjects, more than 200 journals)

Providing 24-hour high-quality service

User-friendly online submission system

Fair and swift peer-review system

Efficient typesetting and proofreading procedure

Display of the result of downloads and visits, as well as the number of cited articles

Maximum dissemination of your research work

Submit your manuscript at: http://papersubmission.scirp.org/

Or contactwjet@scirp.org 